\title{
KAJIAN ETIKA KRISTEN TERHADAP KEBERSIHAN LINGKUNGAN DI KELURAHAN KLABALA
}

\author{
Thomson F. E. Elias ${ }^{1}$, Wiesye A. Wattimury ${ }^{2}$
}

\author{
${ }^{1}$ Universitas Kristen Papua \\ JI. F. Kalasuat, Sorong, \\ Indonesia \\ thomsonelias24@gmail.com \\ ${ }^{2}$ Universitas Kristen Papua \\ JI. F. Kalasuat, Sorong, \\ Indonesia \\ wiesye2504@gmail.com
}

\begin{abstract}
It is based on researchby the lack of knowledge of people around times klabala, about the importance of maintaining clean ( waste management). Lack of infrastructure to support clean, it's existence happened environmental pollution caused its existence and flash floods could not pay the role of the community to the garbage issue as part of efforts to maintain clean environment. This research, uses the technique kualitati, in interviews directly with those who are able to provide information. The results showed that, the lack of public awareness about what it means to clean, and the process of waste management to set back
\end{abstract}

Keywords : hygiene, environment

\section{PENDAHULUAN}

Allah memberikan hak kepada manusia untuk menguasai alam dan segala isinya, maka secara harafiah, manusia diberikan oleh Allah hak asasi, yaitu hak untuk hidup serta hak atas kebebasan. Sebaliknya, dengan hak yang diberikan oleh Allah kepada manusia tidak digunakan secara bijak. Hal tersebut dapat dilihat pada kehidupan umat yang menjalankan wasiat Allah dengan kurang bijak yang tercermin pada perilaku manusia yang memberikan dampak negatif terhadap kualitas lingkungan. Hal ini nampak jelas terlihat pada pola hidup dan atau gaya hidup warga/penduduk kota Sorong.

Seperti diketahui, bahwa kota Sorong tergolong dalam kota kecil, dikatakan kota kecil karena jumlah penduduk kota Sorong masih tergolong dalam kategori kota keci dimana kategori kota kecil memiliki jumlah penduduk sebanyak 100.000 s/d 500.000 jiwa. Sedangkan jumlah penduduk kota Sorong dari data lapangan yang kami peroleh melalui Kepala Bagian Pemerintahan Setd Kota Sorong sebanyak 320.475 jiwa, dan data yang kami dapatkan dari BPS (Badan Pusat Statistik) kota Sorong adalah sebanyak $213.683 \mathrm{jiwa}^{[2]}$.
Dari sisi geografis, letak kota Sorong sangat strategis, karena merupakan pintu keluar masuk Propinsi Papua, dan kota Sorong juga merupakan kota persinggahan. Hal ini menyebabkan laju perkembangan pertumbuhan kota Sorong, dari aspek sosial, ekonomi, budaya cukup pesat. Demikian halnya pada laju pertumbuhan penduduk kota Sorong dari tahun ke tahun mengalami peningkatan sejak berdirinya kota Sorong. (data laju pertumbuhan penduduk terlampir).

Pertumbuhan penduduk yang disertai dengan tingginya arus urbanisasi, menyebabkan meningkatnya berbagai aktifitas sosial ekonomi masyarakat dan pembangunan fasilitas perkotaan seperti; perumahan, pertokoan, pusat bisnis dan indiustri.

Seiring dengan perkembangan kota, pertumbuhan penduduk memicu perningkatan kebutuhan penduduk. Untuk memenuhi kebetuhan dan tuntutan hidup, maka manusia akan melakukan upaya-upaya atau aktifitas yang bertujuan untuk pemenuhan akan kebutuhan hidup tersebut, tanpa memperhatikan akibat/dampak yang dapat terjadi yang berujung pada kualitas lingkungan yang buruk.

Sampah yang dihasilkan, yang dengan berbagai macam cara harus dibuang ke 
lingkungan, (Tong sampah, TPS, halaman rumah, got/selokan, jalan raya dan lain sebagainya). Maka, mengacu dari setiap aktifitas-aktifutas yang dilakkan oleh manusia, dengan demikian tentunya dapatlah dikatakan bahwa kita atau, Setiap kita adalah penghasil sampah, karena dalam setiap aktifitas kehidupan manusia memberikan kontribusi terhadap persoalan sampah.

Permasalahan ini dapat dilihat pada wajah kota Sorong yang dari tahun ke tahun mengalami penurunan kualitas lingkungan dari segi kebersihan kota secara keseluruhan. Penurunan kualitas lingkungan yang dimaksudkan pada bagian pembahasan ini adalah kualitas lingkungan yang berdampak pada aspek estetika lingkungan. Pada aspek estetika ini terkait erat dengan kebersihan lingkungan kota Sorong yaitu, masalah limbah padat/sampah.

Tingkat kebutuhan masyarakat pada akhirnya menyebabkan terjadinya peningkatan jumlah sampah. Berdasarkan data survey dinas kebersihan, kota Sorong potensi persampahan di kota Sorong, sampah yang dihasilkan penduduk/keluarga sama dengan $2,45 \mathrm{~kg}$ per kepala keluarga per hari. Dan setiap KK rata-rata 5 jiwa berdasarkan data ini, maka terhitung setiap orang menghasilkan sampah $0,49 \mathrm{~kg} / \mathrm{hari}$.

Dari data tersebut nampak jelas, bahwa warga kota Sorong belum memahami cara penanganan sampah dengan baik, baik dilingkungan sekitar maupun di kota Sorong secara keseluruhan.Kelurahan Klabala menjadi lokasi studi penelitian adalah salah satu dari 5 (lima) kelurahan yang ada di kota Sorong distrik Sorong Barat, propinsi Papua Barat. Kelurahan Klabala membawahi 12 RW dan 39 RT.

Luas dari wilayah kelurahan Klabala ini mencapai 633.159 Ha. Jumlah jiwa/penduduk yang bermukim di kelurahan Klabala sebanyak kurang lebih 15.546 jiwa. Meningkatnya pertumbuhan penduduk diatas akan berpengaruh juga pada peningkatan aktifitas masyarakat yang memungkinkan menghasilkan sampah yang banyak. Dari hasil wawancara dengan kepala kelurahan Klabala, dapat diketahui bahwa masalah yang berkaitan dengan kebersihan lingkungan di kelurahan Klabala adalah kurangnya kesadaran masyarakat akan kebersihan lingkungan dalam hal penanganan sampah baik dihalaman maupun di kali Klabala, minimnya peralatan/angkutan untuk sampah, juga kegiatan "jumat bersih dan prokasi" (Program Kali Bersih) belum maksimal dilaksanakan oleh masyarakat. Di katakan juga, volume sampah yang banyak adalah di sekitar kali Klabala yang disebabkan oleh rutinitas masyarakat yang tinggal di hulu/tepian kali Klabala dan di sekitar jalan Kalimantan yang membuang sampah dialiran air kali.

Ini berarti bahwa masyarakat di hulu kali belum memahami dampak buruk yang ditimbulkan oleh sampah. Dari realita inilah, maka dapat diidentifikasikan masalah-masalah yang menjadi latar belakang, yaitu, Minimnya pengetahuan warga masyarakat disekitar kali Klabala, tentang pentingnya menjaga kebersihan lingkungan (penanganan sampah),sedangkan Dari sektor/pendekatan pemerintahan, adalah kendala sarana prasarana. Keberadaan sampah juga mengakibatkan terjadi pencemaran lingkungan, Keberadaan sampah dapat mengakibatkan banjir dan wabah penyakit. Dari latarbelakang inilah, maka penelitian ini dilakukan, dalam satu kajian etika Kristen, dan untuk memperoleh data, maka penelitian dilakukan secara kualitatif ,dengan menggunakan teknik wawancara langsung terhadap responden, yang dianggap mampu untuk memberikan data.

\section{KAJIAN LITERATUR}

\subsection{Pengertian Etika}

Secara teori etika mempunyai pengertian sebagai berikut:

Pertama, secara etimologis, etika berasal dari kata Yunani "ethos" yang berarti "adat istiadat" atau "kebiasaan". Dalam arti ini, etika berkaitan dengan kebiasaan hidup yang baik, tata cara hidup yang baik. Baik pada diri seseorang ataupun pada masyarakat. Kebiasaan hidup yang baik ini, dibakukan dalam bentuk aturan atau norma yang pada dasarnya menyangkut baik buruknya perilaku manusia. Singkatnya aturan atau norma ini menentukan apa yang baik harus dilakukan dan apa yang buruk harus dihindari. Dari pengertian tersebut, etika secara lebih luas dipahami sebagai pedoman bagaiman manusia harus hidup dan bertindak sebagai orang yang baik. Etika memberi petunjuk orientasi, arah 
bagaimana harus hidup secara baik sebagai manusia.

Kedua, etika dipahami sebagai refleksi tentang bagaimana manusia harus hidup dan bertindak dalam situasi konkrit, situasi khusus tertentu.

Etika adalah ilmu yang membahas dan mengkaji secara kritis persoalan benar dan salah tentang bagaimana harus bertindak dalam situasi konkrit $^{[8]}$.

Aristoteles, seorang ahli filsafat Yunani menulis untuk Nikomachus, anaknya, sebuah buku, tentang kaidah-kaidah, perbuatan manusia dan buku ini diberinya nama: Ethika Niomacheia. Istilah Etika ini kemudian menjadi "istilah khusus" untuk ilmu pengetahuan yang menyelidiki soal kaidah-kaidah, kelakuan dan perbuatan manusia ${ }^{[10]}$.

Dengan mempelajari defenisi etika diatas adalah sangat penting bagi setiap orang dipahami sebagai tolak ukur hidup yang baik ditengah lingkungan dan masyarakat, secara khusus dalam keterkaitan dengan masalah sampah, karena moral dan perilaku manusia adalah hal mendasar yang dituntut etika dalam berinteraksi dengan lingkungan.

\subsection{Tiga Teori Etika}

Tiga teori etika yang penting untuk dipahami adalah sebagai berikut ${ }^{[10]}$ :

\section{Etika Deontologi}

Istilah "deontologi" berasala dari kata Yunani "deon dan logos". "Deon" yang berarti kewajiban, dan "logos" berarti ilmu atau teori. Terhadap pertanyaan bagaimana bertindak dalam situasi konkrit tertentu deontologi menjawab: lakukan apa yang menjadi kewajibanmu sebagaimana terungkap dalam norma dan atauran-aturan yang ada. Sejalan dengan itu, menurut etika deontologi, suatu tindakan dianggap baik pada diri sendiri dan merupakan kewajiban yang harus di lakukan. Sebaliknya suatu tindakan yang dinilai buruk secara moral sehingga tidak menjadi suatu kewajiban untuk dilakukan. Demikian pula sikap hormat terhadap alam atau menghargai alam ciptaan ini, akan baik kalau itu menjadi sebuah kewajiban moral.

Menurut Kant, kemauan baik harus dinilai baik pada dirinya sendiri terlepas dari apa pun juga. Maka dalam menilai tindakan kita, kemauan baik harus dinilai paling pertama dilakukan dan menjadi kondisi dari segalanya.

Menurut Kant, kemauan baik adalah syarat mutlak untuk bertindak secara moral. Kemauan baik menjadi kondisi mau tidak mau harus dipenuhi agar manusia dapat bertindak secara baik, sekaligus membenarkan tindakannya itu. Atas dasar ini, menurut Kant, tindakan yang baik adalah tindakan yang tidak saja sesuai dengan kewajiban tetapi dijalankan berdasarkan dan demi kewajiban ${ }^{[4]}$.

\section{Etika Teleologi}

Istilah teleologi berasal dari kata Yunani "telos dan logos" telos, yang berarti tujuan, dan logos berarti ilmu atau teori. Berbeda dengan etika deontologi, etika teleologi menjawab pertanyaan bagaimana bertindak dalam situasi konkrit tertentu dengan melihat tujuan atau akibat dari suatu tindakan.

Dengan kata lain, etika teleologi menilai baik buruk suatu tindakan berdasarkan tujuan atau akibat dari tindakan tersebut.

\section{Etika Keutamaan.}

Berbeda dengan etika "deontologi" dan "teleologi", etika keutamaan tidak mempersoalkan akibat suatu tindakan. Juga, tidak mendasarkan penilaian moral pada kewajiban terhadap hukum moral universal. Tetapi etika keutamaan lebih mengutamakan pengembangan karakter moral pada diri setiap orang.

\subsection{Etika lingkungan}

Lingkungan adalah segala sesuatu yang ada di sekitar manusia yang mempengaruhi kelangsungan kehidupan kesejahteraan manusia dan makhluk hidup lainnya.

Jadi, etika lingkungan merupakan kebijaksanaan moral manusia dalam bergaul dengan lingkungannya,.etika lingkungan diperlukan agar setiap kegiatan yang menyangkut lingkungan dipertimbangkan secara cermat sehingga keseimbangan lingkungan tetap terjaga. Yang menjadi fokus perhatian etika lingkungan adalah perilaku manusia dengan alam serta nilai dan prinsip moral yang menjiwai 
perilaku manusia dalam hubungan dengan alam tersebut.

Adapun hal-hal yang harus diperhatikan sehubungan dengan penerapan etika lingkungan hidup dalam kehidupan pribadi maupun dengan sesama dengan lingkungan disekitar adalah sebagai berikut:

a. Manusia merupakan bagian dari lingkungan yang tidak terpisahkan sehingga manusia perlu senantiasa menyayangi semua kehidupan dan lingkungan dimana ia berada, selain dirinya sendiri.

b. Agar menjadi cerminan bagi sesama manusia, Manusia sebagai bagian dari lingkungan, hendaknya selalu berupaya untuk menjaga terhadap pelestarian, keseimbangan dan keindahan alam.

c. Manusia harus menyadari dan memahami bahwa lingkungan disediakan bukan untuk manusia saja, melainkan juga untuk makhluk hidup yang lain sehingga adanya saling ketergantungan dan perlu melestarikannya.

d. Pelestarian dimaksud untuk kelanjutaan pemanfaatan alam dari generasi ke generasi yang akan datang.

Etika Lingkungan tidak hanya berbicara mengenai perilaku manusia terhadap alam, namun juga mengenai relasi di antara semua kehidupan alam semesta, yaitu antara manusia dengan manusia yang mempunyai dampak pada alam dan antara manusia dengan makhluk hidup lain atau dengan alam secara keseluruhan.

\subsection{Sampah (Limbah Padat)}

Salah satu penyebab buruknya pemandangan alam dan lingkungan hidup yang menimbulkan dampak negatif pada masyarakat dan juga pada lingkungan disekitarnya adalah masalah sampah. Sampah yang dapat didefinisikan sebagai segalah sesuatu yang sudah tidak bermanfaat/tidak berguna dan tidak diinginkan oleh pemiliknya lagi.

Limbah disebut juga buangan. Berdasarkan fase atau wujudnya, limbah atau buangan ini terbagi menjadi 3 (tiga) jenis, antara lain: limbah cair, limbah gas, limbah padat. Contoh limbah cair; air bekas cucian pakaian, air bekas cucian piring, air bekas cucian kendaraan, dan lainsebagainya.contoh limbah gas: buanganbuangan berupa asap kendaraan, buanganbuangan dari pabrik, asap hasil pembakaran sampah, dan lain sebagainya. Sedangkan contoh limbah padat atau yang sering disebut sebagai sampah, yaitu berupa plastik pembungkus makanan, kertas pembungkus makana, bahanbahan kemasan pada material atau peralatan tertentu, dan lain sebagainya.

Sampah yang terkumpul bisa dimanfaatkan kembali menjadi beberapa barang yang berguna, ataupun bernilai ekonomis, seperti contoh: bunga yang terbuat dari pembungkus buah apel yang penulis amati di salah satu ruangan SMA Agustinus di Sorong. Sampah juga dapat diolah menjadi pupuk yang bisa bermanfaatkan untuk menyuburkan tanah.

Banyak pandangan-pandangan para ahli tentang sampah, namun dari semua pendefinisian itu memiliki kesamaan bahwa sampah adalah bahan sisa yang membutuhkan perhatian dari kita manusia sebagai penghasil sampah selain proses alam, untuk perwujudan suatu lingkungan yang bersih dan tertata.

\subsection{Klasifikasih Sampah}

Ditinjau dari karakteristiknya, maka limbah padat dapat dibagi menjadi 2 (dua) bagian, yaitu sampah organik dan sampah anorganik.

a. Sampah organik merupakan jenis sampah yang dapat terurai atau dapat membusuk karena proses alam. Sampah organic disebut juga "garbage" contoh sampah jenis ini berupa sisa-sisa makanan, sisa potongan sayur, daging, ikan, dedaunan sampah kayu, jenis sampah ini dapat membusuk karena adanya proses kerja mikroorganisme.

b. Sampah anorganik, yaitu jenis sampah yang tidak dapat terurai atau tidak dapat membusuk karena proses alam. Sampah anorganik disebut juga,"refuse". Contoh sampah anorganik; plastik, kertas, kaca, fiber dan lain sebagainya. Karena jenis sampah anorganik adalah sampah yang tidak dapat terurai, sehingga dibutuhkan tahapan yang disebut proses daur ulang ${ }^{[3]}$. 


\subsection{Sumber Sampah}

Sampah "limbah padat" berasal manusia sebagai sumber penghasil sampah dan tempat/area yang biasanya ditemukan banyak sampah adalah:
a. Perumahan
b. Pertokoan.
c. Perkantoran.
d. Sekolah.
e. Fasilitas umum; (jalan raya, terminal, taman kota, pelabuhan).
f. f.Indistri /pabrik (pengalengan ikan, pabrik krepek dll).

\subsection{Dampak Sampah bagi Kesehatan}

Lokasi dan pengelolaan sampah yang kurang memadai (pembuangan sampah yang tidak terkontrol) merupakan tempat yang cocok bagi beberapa organisme dan menarik bagi berbagai binatang seperti lalat, tikus dan nyamuk yang dapat menimbulkan penyakit.

Potensi bahaya kesehatan yang dapat ditimbulkan sampah adalah sebagai berikut:

1. Penyakit diare, kolera, tifus menyebar dengan cepat karena virus yang berasal dari sampah dengan pengelolaan tidak tepat dapat bercampur air minum. Penyakit demam berdarah (haemorhagic fever) dapat juga meningkat dengan cepat di daerah yang pengelolaan sampahnya kurang memadai.

2. Penyakit jamur dapat juga menyebar (misalnya jamur kulit).

3. Penyakit yang dapat menyebar melalui rantai makanan. Salah satu contohnya adalah suatu penyakit yang dijangkitkan oleh cacing pita (taenia). Cacing ini sebelumnya masuk ke dalam pencernakan binatang ternak melalui makanannya yang berupa sisa makanan/sampah.

4. Jika dibakar, sampah plastik akan menghasilkan asap beracun yang berbahaya bagi kesehatan yaitu jika proses pembakaranya tidak sempurna, plastik akan mengurai di udara sebagai dioksin. Senyawa ini sangat berbahaya bila terhirup manusia. Dampaknya antara lain memicu penyakit kanker, hepatitis, pembengkakan hati, gangguan sistem saraf dan memicu depresi.
Dalam setiap aktifitas kehidupan manusia memberi kontribusi dalam persoalan sampah, ini berarti bahwa setiap kegiatan yang dilakukan berpeluang menghasilakan sampah. Pemahaman yang salah dalam masyarakat mengenai sampah, bahwa sampah hanyalah menjadi tanggung jawab pemerintah ${ }^{[11]}$.

Pemahaman yang keliru ini haruslah dibuang jauh dari pemikiran setiap orang, karena persoalan sampah terutama yang ada dilingkungan adalah tanggung jawab bersama. Dengan demikian maka dapat dipahami bahwa masalah sampah ini adalah masalah bersama dalam arti bahwa dampak yang akan ditimbulkan oleh sampah akan dialami/dirasakan oleh setiap orang yang tidak peduli dengan kebersihan dilingkungan sekitarnya.

Pemahaman sebagian masyarakat adalah bahwa mereka membayar retribusi sampah, untuk itu mereka berhak mendapatkan kompensasi atas retribusi yang telah dibayar tersebut, tanpa disadari oleh masyarakat bahwa ketika sampah Rumah Tangga yang terlambat diambil di TPS (Tempat Pembuangan Sampah), akan mengakibatkan bau busuk yang menjadi tempat persinggahan binatang-binatang yang dapat membawah wabah penyakit seperti lalat,tikus dan nyamuk.

Persoalan yang terjadi dalam lingkungan kelurahan Klabala, khususnya masyarakat yang tinggal di hulu/tepi kali Klabala, dalam kaitan dengan sampah Rumah Tangga adalah sampah Rumah Tangga di buang di kali atau sampah daun-daun yang gugur dari pohon di seklitar rumah akan disapu kearah Kali sehingga pemandangan yang dapat dilihat adalah tumpukan sampah dipinggir kali dan dialiran air Kali Klabala, yang tentunya akan berdampak buruk bagi masyarakat, seperti sumber penyakit dan juga tumpukan sampah yang ada di aliran kali akan mengakibatkan bahaya banjir.

Permasalahan ini harusnya dapat memberi kesadaran dan pemahaman yang baik kepada masyarakat bahwa semua warga/masyarakat harus ikut berperan dalam menjaga membersihan lingkungan dari sampah, agar kebersihan disekitar tempat tinggal dan di Kali Klabala juga disekitar dapat diperhatikan dan dijaga secara berkesinambungan. Sebab 
dampaknya akan dirasakan oleh setiap masyarakat yang ada disekitarnya.

\section{METODE PENELITIAN}

\subsection{Tujuan Penelitian}

Sebelum mengkaji lebih dalam metode yang dipakai dalam penelitian maka perlu memperhatikan kembali tujuan dari penelitian itu sendiri yaitu:

1. Meneliti dan berusaha menemukan jawaban mengapa masyarakat yang tinggal disekitar hulu/pinggiran kali Klabala menjadikan kali Klabala sebagai tempat pembuangan sampah.

2. Melakukan kajian etika Kristen

Demi tercapainya tujuan penelitian maka digunakan metode penelitian kualitatifdeskriptif. Model penelitian kualitatif adalah prosedur penelitian yang menghasilkan data deskriptif berupa kata-kata tulisan atau lisan dari orang-orang dan prilaku yang diamati ${ }^{[6]}$. Peneliti berusaha menemukan teori-teori substansi atau formal yang kesemuanya berasal dari data.

Selanjutnya metode deskriptif adalah: Suatu metode yang mempelajari masalahmasalah dalam masyarakat serta tata cara yang berlaku dalam masyarakat dan situasi-situasi tertentu termasuk tentang hubungan kegiatankegiatan, sikap-sikap, pandangan-pandangan serta proses-proses yang sedang berlangsung dan pengaruh-pengaruh dari suatu fenomena atau gejala $^{[7]}$.

\subsection{Tempat dan Waktu Penelitian Penelitian}

Penelitian ini dilakukan di kelurahan Klabala distrik Sorong Barat Papua Barat, lebih terfokus pada lokasi studi yaitu kali Klabala dan masyarakat yang berdomisili disekitarnya

\subsection{Metode Penelitian}

Ada 5 metode penelitian yang penulis pakai dalam studi penelitian ini yaitu:

\section{a. Observasi}

Dalam penelitian ini, penulis menggunakan observasi secara langsung. Observasi langsung adalah mengamati dan mendengar secara langsung dalam rangka mencari jawab, mencari bukti terhadap fenomena yang ada ${ }^{[9]}$.

b. Wawancara
Peneliti menggunakan jenis wawancara terbuka, yakni responden tahu mereka sedang diwawancarai dan mengetahui maksud wawancara tersebut, dan mereka dapat memberikan informasi sebesarbesarnya.

c. Studi Pustaka

Selain observasi dan wawancara, peneliti juga menggunakan beberapa literatur untuk menunjang penulisan.

Dalam mengumpulkan data, dapat dilakukan dengan cara mempelajari dokumen-dokumen yang menunjang penelitian yang sedang dilakukan ${ }^{[5]}$.

\subsection{Populasi Teknik Pengambilan Sampel dan Jumlah Sampel}

Populasi adalah seluruh subjek penelitian ${ }^{[1]}$. Yaitu seluruh anggota Pemuda. Namun dikarenakan keterbatasan waktu dan dana maka peneliti menggunakan teknik sampel bertujuan. Pengambilan sampel bertujuan ini didasarkan pada ciri-ciri, sifat-sifat atau karakter-karakter yang merupakan ciri-ciri pokok populasi.

Adapun banyaknya sampel yang diambil penulis sebanyak 100 orang. Penetapan 100 orang ini berdasarkan karateristik yang diambil dari responden, karakteristik yang dilihat dari responden adalah orang-orang yang berkaitan dengan judul penelitian ini dan dapat memberikan pemahaman tentang sampah dan lingkungan. Oleh karena itu, responden yang penulis pilih adalah anggota Masyarakat, tokoh agama Kepala Dinas kebersihan Kota Sorong, Kepala Kelurahan Klabala dan masyarakat yang tinggal di hulu/pinggiran kali Klabala.

\subsection{Hipotesa}

Masalah sampah dapat menimbulkan dampak negatif pada masyarakat, maupun juga pada lingkungan. Melihat keadaan di lokasi penelitian yaitu di kelurahan Klabala, dengan adanya:

a. Pertambahan jumlah penduduk, yang berpengaruh pada peningkatan aktifitas masyarakat yang menyebabkan sampah yang dihasilkan semakin bertambah.

b. Kurangnya Sarana dan prasarana, tidak tersedianya TPS (Tempat Pembuangan Sampah) untuk Kelurahan Klabala yang 
memadai, sehingga menyebabkan masyarakat yang berada dipingiran kali dan sekitarnya membuang sampah di kali Klabala,

c. Kurangnya kesadaran dan peran masyarakat tentang arti pentingnya menjaga kebersihan lingkungan,

d. Rutinitas masyarakat yang membuang sampah di kali Klabala,

Tentunya diperkirakan hal ini dapat berdampak buruk bagi masyarakat dan lingkungan dengan adanya pemandangan yang kotor karena dipenuhi sampah di sepanjang kali Klabala. Dan memungkinkan adanya banjir yang akan disertai dengan luapan sampah yang berdampak juga pada masyarakat (menurunnya nilai estetika lingkungan). Tanpa penanganan yang serius dari pihak pemerintah dan masyarakat, masalah sampah di kali Klabala dapat juga dipastikan akan berpengaruh pada kesehatan masyarakat.

Tanpa peran/keterlibatan,kesadaran tidak cukup untuk mengatasi masalah sampah dalam kelurahan Klabala. Untuk itu dibutuhkan kesadaran sekaligus peranserta atau keterlibatan penduduk Kelurahan klabala, dalam menyikapi permasalah sampah yang ada dikali Klabala, terutama berpartisipasi atau terlibat dalam kegiatan pemerintah

\section{HASIL DAN PEMBAHASAN}

Dari data wawancara dapat diperoleh penjelasan dari kepala DKP kota Sorong tentang berbagai jenis kegiatan yang sudah dan sementara dilakukan oleh pihak pemerintah kota Sorong dalam hal ini yang dikerjakan oleh dinas kebersihan secara khusus di kelurahan Klabala.

\section{a. Jenis Kegiatan Pembersihan yang}

Dilakukan di Kelurahan Klabala

Dengan wilayah pelayanan yang cukup luas pada wilayah kelurahan Klabala, maka dinas terkait bekerjasama dengan pihak ketiga guna pelaksanaan kebersihan. Sehingga fungsi pengawasan dan pengontrol diupayakan semaksimal dan seoptimal mungkin oleh pemerintah dalam hal ini dinas terkait, yaitu dinas kebersihan dan pertamanan kota sehingga selaras dengan apa yang tertuang pada Visi Missi kota Sorong : "Kota Sorong Kota Termaju
Di Tanah Papua." Kegiatan pembersihan kota sorong pada daerah pelayanan terfokus pada wilayah studi, dilakukan dengan beberapa jenis kegiatan yaitu:

1. Kegiatan pembabatan

Kegiatan pembabatan dilakukan oleh pihak ketiga. Kegiatan ini dilakukan dengan jadual sekali tiap bulan. Tenaga kerja yang difokuskan pada kegiatan pembabatan ini, dibagi dalam 2 kelompok tim pembabatan dalam jadual sekali pembabatan, yaitu sebagian tim membabat rumput atau tanaman liar pada ruas jalan sebelahnya sementara sebagian tim lainnya mengambil lokasi bagian pembabatan pada ruas jalan disebelahnya. Kegiatan pembabatan ini dilakukan oleh tenaga kerja pria.

\section{Kegiatan penyapuan}

Kegiatan penyapuan terbagi menjadi 2 bagian yaitu:

a) Kegiatan penyapuan bulanan

Kegiatan penyapuan dilakukan oleh pihak ketiga. Kegiatan ini dilakukan dengan jadual penyapuan sekali tiap bulan. Tenaga kerja yang difokuskan pada kegiatan penyapuan ini dibagi dalam 2 kelompok tim penyapuan dalam jadual sekali pembabatan, yaitu sebagian tim mengambil tugas penyapuan pada ruas bidang jalan yang telah dibabat, sementara sebagian tim penyapuan lainnya mengambil tugas penyapuan pada ruas bidang jalan sebelahnya. Kegiatan penyapuan ini dilakukan oleh tenaga kerja wanita.

b) Kegiatan penyapuan harian.

Kegiatan penyapuan harian ini juga dilakukan oleh dinas kebersihan dan pertamanan kota Sorong yang bekerjasama dengan pihak ketiga (pihak kontraktor). Pada wilayah pelayanan terfokus pada wilayah studi yaitu wilayah kelurahan klabala juga rutin dilakukan kegiatan penyapuan. Kegiatan penyapuan ini dikerjakan oleh tenaga kerja wanita dengan teknik penyapuan yang sama dengan yang dilakukan pada penyapuan bulanan.

\section{Kegiatan pengangkutan sampah}

Kegiatan pengangkutan sampah pada wilayah pelayanan sekota Sorong dilakukan oleh pemerintah terkait yaitu dinas kebersihan dan pertamanan kota Sorong yang mana telah 
bekerjasama dengan pihak ketiga dalam fokus kegiatan pengangkutan sampah kota. Kegiatan pengangkutan sampah yang dihasilkan oleh warga atau penduduk yang berdomisili pada wilayah studi (kelurahan Klabala) juga dilakukan oleh pihak ketiga tersebut.

Dalam kegiatan pengangkutan sampah diperhatikan beberapa faktor sebagai berikut :

a) Luasan wilayah pelayanan

Dengan melihat pada cakupan luasan wilayah yang dilayani di wilayah distrik sorong barat, maka luasan wilayah pelayan dibagi menjadi 2 bagian besar. Hal ini tentunya berkaitan dengan jumlah sarana prasana yang dibutuhkan (Semakin luas daerah pelayanan semakin banyak jumlah sarana prasaran yang dibutuhkan). Untuk wilayah pelayanan kebersihan pada kelurahan Klabala mengambil rute pada wilayah :

1. Wilayah jalan Misol - Raja Ampat

2. Wilayah batasan antara kelurahan Klabala Klasur.

3. Wilayah ruasan jalan arteri Jl. Sam Ratulangi - kompleks Surya.

4. Wilayah ruasan jalan Kalimantan hingga

5. Wilayah ruasan jalan Arteri Gunung Arfak.

b) Jumlah tenaga kerja pada luasan wilayah pelayanan

Dengan luasan wilayah yang luas maka dibutuhkan jumlah sarana prasarana yang lebih, secara langsung menambah jumlah tenaga kerja untuk proses pengangkutan sampah dari TPS menuju ke TPA. Jumlah tenaga kerja yang disediakan untuk pemindahan sampah dari lokasi penimbunan sampah ke dalam dump truck dibutuhkan 5-7 orang tenaga kerja. Dalam tim kerja kegiatan pengangkutan sampah dari TPS ke dump truck dibagi menjadi 3 kelompok tim teknik operasional, yaitu:

1. Tiga orang tenaga yang bertugas untuk mencangkul/menyekop sampah dipindahkan ke karung atau wadah transfer.

2. Dua orang tenaga kerja yang bertugas untuk memindahkan sampah dari karung/wadah transfer ke dalam dump truck.

2. Dua orang tenaga kerja yang bertugas meratakan sampah yang sudah ada dalam dump truck, tujuannya agar mencegah kelebihan pemakaian luasan ruang bak terbuka dari dump truck tersebut.

c) Jumlah sarana prasarana pada luasan wilayah pelayanan

Jenis sarana prasarana yang digunakan untuk pengangkutan sampah yaitu truck sampah. Untuk wilayah kelurahan klabala dilayani dengan 1 (satu) dump truck. Di wilayah kelurahan Klabala tidak terdapat bak sampah resmi yang dimiliki oleh dinas kebersihan dan ditempatkan sebagai tempat penampungan sampah sementara, sehingga sebagian masyarakat membuang sampah di samping hotel Mambramo dan di belakang SD Negeri 1 Kampung Baru. Terdapat juga tempat penampungan sampah sementara yang juga lebih banyak dibuat dengan sendirinya oleh warga masyarakat, sehingga dengan melihat hal ini, maka dari dinas terkait mencoba menutup beberapa lokasi penampungan sampah sementara yang dibuat oleh masyarakat kelurahan Klabala. Dengan melihat hal tersebut, maka lokasi tempat penampungan sampah sementara yang dipakai adalah didepan RS Kampung Baru berjumlah 1 unit dari bahan baja berbentuk kotak persegi panjang terbuka, Dan satu TPS sementara di belakang SD Negeri 1 Kampung Baru berupa bak parmanen.

\section{Metode Kerja Pembuangan sampah}

Metode yang terpakai pada pelayanan kebersihan di wilayah kelurahan Klabala ada beberapa tipe:

1. Sampah dari warga dibawah ke TPS dan dari TPS akan diangkut oleh dump truck dibuang ke TPA.

2. Sampah dari warga diletakan didepan rumah dan petugas pengangkutan sampah mengambilnya kemudian menuju ke TPS untuk mengambil sampah pada TPS untuk kemudian dibawah ke pembuangan akhir atau TPA.

Untuk metode ini, dilakukan jika ruas jalan akses memungkinan untuk dilalui oleh dump truck. Jika ruas jalan tidak dapat diakses oleh dump truck maka warga wajib membawa sampahnya ke lokasi TPS. 
Pada bagian ini nampak kendala yang muncul, antara lain seperti warga beranggapan bahwa adanya pelayanan hingga jalan lingkungan, sehingga nampak warga lebih memilih untuk menempatkan sampah rumah tangga yang dihasilkan, didepan rumah dengan harapan akan adanya pelayanan pengambilan sampah didepan rumah tanpa warga masyarakat tersebut melihat kondisi jalan (akses jalan dapat dilalui oleh dump truck atau tidak)

\section{Kendala-kendala pada wilayah pelayanan}

Berdasarkan hasil analisa data wawancara dan penelitian lapangan maka diketahui beberapa kendala yang berkaitan dengan masalah sampah yang ada di wilayah studi yaitu dikelurahan Klabala, diantaranya:

1) Minimnya kesadaran warga masyarakat yang masih membuang sampah diseputaran kali Klabala/kompleks Surya, sepanjang drainase atau saluran-saluran air bahkan dihutan dan atau dijalan raya.

2) Masih ada warga yang menempatkan sampah didepan rumah mereka, tanpa memikirkan akses jalan dari truck pengangkut sampah ada atau tidak.

3) Kendala pada point nomor 2 diatas menimbulkan masalah turunan yaitu estetika.

4) Dengan penyediaan jumlah tempat sampah sementara "container" yang minim, ditambah dengan penutupan beberapa lokasi-lokasi TPS, menyebabkan timbulnya kecenderungan warga masyarakat untuk membuang sampah disembarang tempat.

5) Dengan sarana prasarana serta jumlah tenaga kerja yang terbatas dengan waktu produktif dalam sehari yang dapat digunakan untuk pelayanan masyarakat terbatas, maka dari dinas terkait mengeluarkan aturan jam buang sampah yaitu mulai dari pukul 18:00 hingga pukul 06:00. Walaupun sudah ada peraturan yang dibuat demikian, namun tidak sedikit warga yang menyadari untuk dapat menerapkannya. Kendala yang timbul adalah daerah layanan lain tidak dapat dilayani secara optimal.

6) Tidak bersedianya masyarakat untuk memberikan tempat atau lokasi mereka untuk dipergunakan sebagai lokasi Tempat Penampungan Sampah sementara.

\section{Kajian Etika Kristen}

Dalam kitab Kejadian pasal 1 (satu) tentang cerita penciptaan dikatakan bahwa manusia diciptakan bersama dengan seluruh alam semesta. Itu berarti bahwa manusia memiliki keterkaitan, ketergantungan dan kesatuan dengan lingkungan hidupnya. Akan tetapi, dikatakan dalam ayat 26 bahwa manusia diciptakan serupa dan segambar dengan Allah "Imago Dei" dan yang diberikan kewenangan untuk menguasai dan menaklukkan bumi dengan segala isinya. Sehingga dapat dikatakan bahwa manusia adalah bagian integral dari ciptaan (lingkungan), akan tetapi di lain segi, ia diberikan kekuasaan untuk memerintah dan memelihara bumi. Maka hubungan manusia dengan lingkungan hidupnya saling ketergantungan satu dengan yang lainnya.

Oleh karena itu, manusia perlu memelihara lingkungan hidup sebagai ungkapan syukur pada Allah Sang Pencipta yang telah mengaruniakan lingkungan dengan segala keindahan dan kekayaan di dalamnya untuk menopang hidup manusia. Dalam konteks ini, manusia sebagai makluk yang mulia memiliki tanggungjawab yang besar untuk mengelolah alam. Mengelolah alam tidak berarati manusia manjadikan alam sebagai objek yang menyenangkan hati manusia, tetapi terlebih juga menyenangkan hati Tuhan Jelaslah bahwa harus terjadi transformasi atas perilaku manusia yang semena-mena terhadap alam/lingkungan hidup.

Dengan demikian perilaku membuang sampah secara sembarangan dalam permasalahan yang nampak pada penulisan Penelitian ini merupakan bentuk perusakan lingkungan sebagai pemberian dan anugerah Allah. Transformasi yang dimaksudkan menghendaki manusia untuk tertip sampah, membuangnnya pada tempatnya serta mampu mengelolahnya secara baik demi kesejahteraan manusia itu sendiri. Dengan demikian hendaknya pemahaman dan perilaku menjaga agar lingkungan tetap bersih dan menghargai lingkunngan secara perlahan akan menjadi kebiasaan yang membudaya dalam hidup setiap manusia. 
Masalah sampah bukan saja masalah pada satu kelurahan atau kota tetapi masalah sampah juga dihadapi semua kota di Indonesia dimana permasalah ini mengakibatkan dampak buruk bagi manusia dan lingkungan sebab karena keberadaan sampah yang banyak menimbulkan baik banjir maupun masalah penyakit yang ditularkan oleh binatang-binatang seperti lalat, nyamuk dan tikus, bahkan bau busuk yang bisa menggangu pernafasan.

Oleh karena itu maka permasalahan kebersihan lingkungan di kelurahan Klabala yang terfokus pada masalah sampah yang ada di kali Klabala ini, disebabkan masalah kurangnya kesadaran, peranan dan keikutsertaan masyarakat yang merupakan bagian (warga) dari kelurahan Klabala ini, dalam setiap kegiatan/program baik Prokasi maupun Jumat Bersih dari kelurahan Klabala.

Oleh karena itu, dengan melihat kebiasaan ataupun rutinitas masyarakat yang tentunya berdampak buruk, baik bagi lingkungan maupun bagi masyarakat serta kurangnya kesadaran dan keterlibatan pemuda dalam kegiatan pemerintah maupun gereja, maka pendekatan etika kristen diharapkan mampu menjawab permasalahan yang ada. Pendekatan ini diharapkan mampu untuk menyadarkan kita dalam menentukan sikap, tindakan/perilaku yang baik dalam memperlakukan alam ciptaan Tuhan, serta mampu menunjukan jati diri kita sebagai orangorang kristen.

Ketiga teori etika disini akan dipakai untuk menjawab pertanyaan bagaimana menilai sesuatu tindakan yang baik secara moral. Serta melihat bagaimana peranan pemuda yang pada dasarnya sebagai tulang punggung gereja. Tiga teori tersebut adalah:

\section{Teori Etika Deontologi}

Yang menjadi sorotan pada permasalah ini adalah " peranan" dari masyarakat dalam menyikapi masalah yang ada. Kalau berbicara perana berarti berbicara tindakan atau karakter.

Kali semakin kotor masyarakat hanya mempersalahkan pihak pemerintah, dan pemuda-pemudi tidak menunjukan peranan yang baik hanya beralasan bahwa tidak ada program kerja dari gereja ataupun tidak ada sosialisasi yang baik dari RT/RW maka timbul pertanyaan bagaimana seharusnya bentuk kepedulian itu dimiliki oleh warga masyarakat, dengan memiliki tanggung jawab menjaga, memelihara, dan melestarikan lingkungan dimana kita berpijak terutama dalam menjaga kebersihan dan menangani masalah sampah yang ada di lingkungan kelurahan Klabala atau disekitar, tanpa kita menunggu komando dari orang lain atau menunggu adanya penetapan program baik dari tingkat kelurahan atau gereja.

Seharusnya, masyarakat sebagai umat cipataan Tuhan bisa membuat Tuhan bersukacita dengan setiap tindakan atau perbuatan sebagai implementasi iman percaya kepada-Nya, dengan menjaga, memelihara dan merawat alam lingkungan dimana kita berada. Bukankah semua yang Dia ciptakan itu baik adanya? Itulah yang di gambarkan kitab Mazmur 104.

\section{Teori Etika teleologi}

Ketika kita memahami bahwa etika membahas tentang baik buruknya tingkalaku seseorang maka, sorotan pada rutinitas masyarakat yang membuang sampah dikali dan adalah persoalan estetika atau dengan kata lain, menurunnya nilai estetika kota dengan pemandangan tumpukan sampah yang ada dikali. Oleh sebab itu peranan ataupun keterlibatan adalah bagian dari pelayanan dan pelayanan memiliki nilai-nilai rohani. Dan bahkan juga ketika memfasilitasi dengan sarana dan prasarana seperti TPS adalah perwujudan dari nilai-nilai pelayanan. Mematuhi aturan ataupun larangan pemerintah untuk tidak membuang sampah dikali adalah memiliki nilai pula.

Namun dari kenyataan yang ada aturanaturan yang sudah dibuat pemerintah seperti tidak membuang sampah disembarang tempat, atau pemberlakuan jam membuang sampah yang bertujuan untuk menciptakan lingkungan yang bersih dan indah, lingkungan yang tertata dan terawat, lingkungan yang bebas wabah penyakit, lingkungan yang asri bagi masyarakat, memang baik dan memiliki nilai positif setiap aturan dari pemerintah untuk melarang masyarakat membuang sampah, karena dapat dipastikan ketika aturan itu dilanggar maka akibatnya adalah bahaya yang mengancam seperti banjir, wabah penyakit dan lingkungan yang kotor. 
Dari hasil penelitian lapangan yang ada adalah pemandangan yang kotor dikali Klabala, banyaknya jenis sampah yang bertumpuk dikali Klabala, memperlihatkan dan memberi gambaran bahwa tidak etisnya tindakan dari, warga masyarakat. Saya beralasan bahwa; "pemahaman tentang sampah dan dampaknya sudah ada tetapi pelaksanaannya yang belum dilakukan sehingga nilai-nilai estetika kota terabaikan dan juga tanpa berpikir bahwa akibat dari kurangnya peranan dalam menjaga kelestarian lingkungan yang akibatnya/dampaknya juga dirasakan oleh semua warga/masyarakat yang berdomisili di kelurahan Klabala.

\section{Teori Etika Keutamaan}

Dalam proses penciptaan, Allah tidak hanya menciptakan manusia tetapi Allah memberi tanggung jawab moral bagi manusia, sebagai aplikasi iman kepadaNya. Lalu pertanyaanya bagi kita, "apa yang harus kita buat ketika kita melihat kenyataan yang ada bahwa kali Klabala tercemar dan kotor?" Tanggung jawab yang diberikan Allah kepada kita untuk mengusahakan bumi harusnya diaplikasikan dengan mampu menjaga keutuhan ciptaan Allah agar tanggung jawab itu tidak sia-sia diberikan Allah kepada Kita. Lalu langkah apa yang harus diambil agar benar-benar kita mampu melaksanakan kehendak Allah?.kita harus sanggup menjadi contoh dan teladan bagi sesama kita dalam menjalani kehidupan dilingkungan dimana kita berada, kita harus mampu menjadi panutan bagi sesama dan kita harus mampu membuat Allah tersenyum dengan setiap tindakan kita.

Tetapi betapa disayangkan kenyataan pada lapangan tempat penelitian adanya kurangnya pemahaman antara "Perbuatan, Iman, dan Pengetahuan". Dalam kitab yakobus 2:26, "sebab seperti tubuh tanpa roh adalah mati, demikian jugalah iman tanpa perbuatanperbuatan adalah mati." Saya memahami bahwa secara keseluruhan narasumber wawancara, dan juga narasumber angket adalah orang Kristen, lalu bagaiman dengan jatidiri sebagai orang kristen yang menjadikan Kristus sebagai teladannya. Berpatokan dari hasil penelitian ini saya beranggapan bahwa, iman kepada Yesus
Kristus tidak diaplikasikan dalam kehidupan bermasyarakat berbangsa dan bergereja, dalam arti bahwa kenyataan yang ditemui dalam penelitian lapangan sampah berserakan di kali atau tidak terlibatnya pemuda-pemudi dalam kegiatan kebersihan lingkungan, untuk suatu kepentingan bersama. Begitu juga dengan pengetahuan yang tidak diaplikasikan dalam kehidupan nyata.

\section{KESIMPULAN}

Sampah merupakan bahan sisa yang tidak digunakan/dibuang oleh pemiliknya. Sampah yang ada di kelurahan Klabala secara khusus dikali Klabala adalah sampah yang berasal dari Rumah Tangga, (warga yang bermukim di sekitar kali Klabala). Tumpukan sampah ini lama kelamaan pasti akan berdampak buruk bagi warga disekitarnya. Bagaimana solusinya? Pemerintah kelurahan Klabala sudah pernah melakukan kegiatan Prokasih (Program Kali Bersih) namun tidak rutin dilaksanakan, justru sebagian besar warga mengharapkan adanya TPS (Tempat Penampungan Sampah) oleh karena kelurahan Klabala belum memiliki sarana TPS, yang seharusnya menjadi tanggung jawab pemerintah. Namun disisi lain tidak ada warga masyarakat yang bersedia memberikan tempat (lahan) untuk menempatkan TPS tersebut.

Seruan dan harapan dari warga masyarakat kepada pemerintah adalah "adanya TPS dan kendaraan yang mampu menjangkau rumah/pemukiman warga.

Harapan-harapan ini seharusnya menjadi "cambuk" bagi masyarakat, agar lebih meningkatkan peranan dibidang lingkungan, khususnya dikota Sorong. Sehingga Visi dan Misi kota sorong yaitu "Sorong Bersih Indah dan Bersahaja" Karena pemahaman atau pengetahuan belumlah cukup untuk menyelesaikan masalah sampah di kali Klabala, tetapi harus disertai dengan tindakan yang nyata untuk kepentingan bersama.

\section{DAFTAR PUSTAKA}

[1] Arikunto, S., "Prosedur Penelitian", (Jakarta: Rineka Cipta, 1988)

[2] BPS Kota Sorong, "Estimasi Jumlah Penduduk Kota Sorong Per Kelurahan." Remu Utara,13/6/2014. 
[3] Homer E., dan Homer. H, pemerhati lingkungan. "Sosialisasi Kebersihan Kota dan Persampahan", CV.Endora's

[4] Kant, I, "Foundations of Metaphysics of Morals" (Indianapolis: Bobbs-Marrill Education, 1980

[5] Merdalis, "Metode Penelitian; Suatu Pendekatan Proposal "(Jakarta: Bumi Aksara, 1993)

[6] Moleong, L., J Metode Penelitian Kualitatif (Bandung: Ramaja Rosda Karya Karya, 1989),

[7] Nazir, M., Metode Penelitan (Jakarta: Galia Indonesia, 1988)
[8] Sonny, K., A., "Etika Lingkungan", (Jakarta: Penerbit Buku Kompas, 2002)

[9] Tobroni, I., S "Metode penelitian Sosial Agama" (Bandung: PT. Ramatja Ros Dakarya, 2001

[10] Verkuyl, J. "Etika Kristen" (Jakarta: BPK Gunung Mulia, 2000).

[11] Seminar Nasional, Institut Teknologi Adhi Tama Surabaya. "Sampah Kota, Masalah Solusi dan Prospeknya"(Surabaya: 14 Januari 2003) 